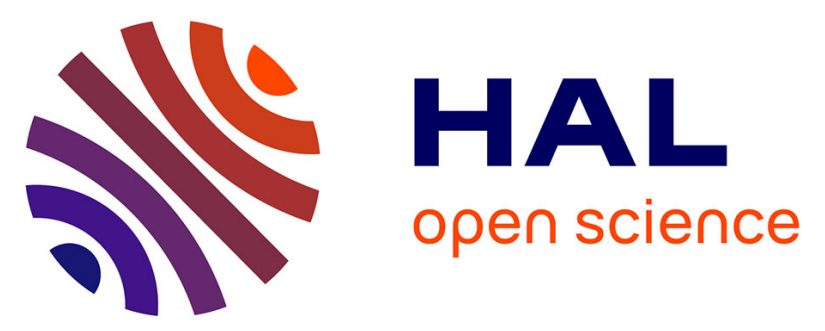

\title{
Otolith shape analysis and mitochondrial DNA markers distinguish three sand smelt species in the Atherina boyeri species complex in western Mediterranean
}

\author{
A. S. Boudinar, L. Chaoui, J. P. Quignard, D. Aurelle, M. H. Kara
}

\section{- To cite this version:}

A. S. Boudinar, L. Chaoui, J. P. Quignard, D. Aurelle, M. H. Kara. Otolith shape analysis and mitochondrial DNA markers distinguish three sand smelt species in the Atherina boyeri species complex in western Mediterranean. Estuarine, Coastal and Shelf Science, 2016, 182 (A), pp.202-210. 10.1016/j.ecss.2016.09.019 . hal-01444074

\section{HAL Id: hal-01444074 \\ https://hal.science/hal-01444074}

Submitted on 1 Mar 2022

HAL is a multi-disciplinary open access archive for the deposit and dissemination of scientific research documents, whether they are published or not. The documents may come from teaching and research institutions in France or abroad, or from public or private research centers.
L'archive ouverte pluridisciplinaire HAL, est destinée au dépôt et à la diffusion de documents scientifiques de niveau recherche, publiés ou non, émanant des établissements d'enseignement et de recherche français ou étrangers, des laboratoires publics ou privés. 
1 Otolith shape analysis and mitochondrial DNA markers distinguish three sand smelt

2 species in the Atherina boyeri species complex in western Mediterranean.

3 Boudinar A.S. ${ }^{a}$, Chaoui L. ${ }^{a}$, Quignard J.P. ${ }^{\mathrm{b}}$, Aurelle D. ${ }^{\mathrm{c}}$, Kara M.H ${ }^{\mathrm{a}^{*}}$

$4 \quad$ aababoratoire Bioressources marines, Université d' Annaba Badji Mokhtar, Annaba, Algérie

$5 \quad$ baboratoire d'ichtyologie, Université Montpellier II, Montpellier, France.

$6 \quad{ }^{\mathrm{c}}$ Aix-Marseille Université, CNRS, IMBE UMR 7263, 13007, Marseille, France.

7

8

9

*Corresponding author: M. H. Kara, Laboratoire Bioressources marines, Université d'Annaba Badji Mokhtar, Algérie. Tel: +213 77 0312458. Fax number: +213 38 868510. E-mail: kara_hichem@yahoo.com

BOUDINAR AHMED SOFIANE : boudinar-2009@live.fr

CHAOUI LAMYA : chaouilamya@ hotmail.com

QUIGNARD JEAN-PIERRE : qjp2@wanadoo.fr

AURELLE DIDIER : didier.aurelle@univ-amu.fr

KARA MOHAMED HICHEM : kara_hichem@yahoo.com 


\section{Abstract}

Atherina boyeri is a common euryhaline teleost fish in the Mediterranean and adjacent areas, which inhabits coastal and estuarine waters, including coastal lagoons and more rarely inland waters. Several recent studies have pointed the possible existence of three distinct groups or species, one lagoon/freshwater group and two 'punctuated and unpunctuated on the flanks' marine groups, within an A. boyeri species complex. This study is a combined approach using otolith shape and molecular markers to better define the structure of the species in the western Mediterranean.

Genetic differentiation and species delimitation among nine Atherina boyeri populations from several marine and lagoon/brakish habitat sites in Algeria, Tunisia and France were investigated using three mitochondrial (control region, $C y t b$ and $16 \mathrm{~S}$ ) and one nuclear markers $\left(2^{\text {nd }}\right.$ intron of S7). For further phylogenetic and phylogeographic study, we added sequences from Genbank covering more areas (Ionian Sea, Adriatic Sea, Tyrrhenian Sea, Black Sea, Atlantic). Five groups were found. Two of them perfectly corresponded to two species already recognized Atherina presbyter and Atherina hepsetus, both living in marine waters; and three additional, including Atherina boyeri (brackish and freshwater environments) and two independent groups of marine punctated and unpunctated individuals. Those findings are corroborated by the study of the otolith contour shape of 362 individuals of seven populations from different habitats using Fourier analysis. Individuals could be discriminated into five groups based on the first two functions (Wilk's lambda $=0.07, \mathrm{p}<$ 0.001). Samples from Ziama inlet, marine punctuated individuals and unpunctuated marine specimens from Annaba's Gulf formed three well separated groups. Specimens from Mellah and Mauguio lagoons formed another group. The last one includes individuals from Bizerte and Thau lagoons. The divergences between them strongly support the potential species within the $A$. boyeri species complex.

Keywords: Atherina boyeri species complex; mt-DNA; Mediterranean Sea; Fourier analysis; genetic divergence 


\section{Introduction}

The Mediterranean Sea had a complex history, marked by the Messinian salinity crisis and climatic fluctuations of the recent Quaternary, characterized with the succession of glacial and interglacial periods. These events induced habitat fragmentation and alteration of connections between populations, and resulted in the establishment of its current biodiversity and of different biogeographical zones (Krijgsman et al., 1999; Patarnello et al., 2007). The Mediterranean Sea is now characterized by a high biodiversity with a quarter of endemic species (Bianchi et al., 2012). Despite decades of dedicated studies, knowledges on biodiversity still evolving, even for well known groups such as fishes (Bianchi et al., 2012). The development of genetic approaches allows a better analysis of species limits, for example by identifying cryptic species (Borsa et al., 2004; Pante et al., 2015). The comparison of genetic and morphological data can bring useful information on the evolution of characters used for species delimitation, on morphological plasticity, and on species interactions (differentiation $v s$ gene flow).

The Atherina Linnaeus, 1758 genus has been a subject of several major systematic revisions (Kiener and Spillmann, 1969), where two genera and 20 species were condensed into a single genus. In Europe the Atherinidae family is represented by a single genus and three species: Atherina boyeri Risso, 1810, Atherina hepsetus Linnaeus, 1758 and Atherina presbyter Cuvier, 1829. Atherina hepsetus is restricted to the Mediterranean, although it has also been reported in the eastern Atlantic coasts of Spain, Morocco, Madeira and Canary Islands (Quignard and Pras, 1986). The distribution of A. presbyter ranges from the British Isles and southern North Sea to the Canary Islands, Mauritania and Cape Verde (Quignard and Pras, 1986). It has also been reported from the Azores archipelago (Santos et al., 1997) and rarely from the western Mediterranean (Kiener and Spillmann, 1969; Quignard and Pras, 1986). Atherina boyeri has been described as an extremely euryhaline teleost fish which can take a wide range of salinities, from freshwater to hypersaline conditions (110\%o maximum recorded) (Gon and Ben-Tuvia, 1983). It mainly inhabits coastal waters of the East Atlantic Ocean as well as in the Mediterranean, Black, Caspian and Aral seas, including estuarine waters, coastal lagoons and more rarely inland waters (Gon and Ben-Tuvia, 1983; Henderson and Bamber, 1987). This small fish forms local semi-isolated populations each with a characteristic morphology and life history traits (Henderson and Bamber, 1987). This species could be a good model to study differentiation and speciation in the Mediterranean Sea with a range spanning important phylogeographical limits and with important morphological diversity according to geography and habitats. Kottelat (1997) pointed out the possible 
1 existence of two different groups in A. boyeri s.l., one belonging to the lagoon / freshwater

2 environment and the other to the marine one. This author limited the name of A. boyeri to the lagoonal form and proposed A. mochon Cuvier, 1829 for the marine one.

Several investigations based on morphometry (Kartas and Trabelsi 1990; Trabelsi et al., 2002a, 2004, Boudinar et al., 2015), and allozymic analyses (Focant et al., 1992, 1993, 1999; Cammarata et al., 1996) supported the hypothesis that A. boyeri could be subdivided into separate sub-populations or species. Data based on allozymic analysis alone (Mauro et al., 2007), or combined with morphometry (Trabelsi et al., 2002a, 2002b, 2004) pointed out the existence of two (Klossa-Kilia et al., 2002, 2007; Kraitsek et al., 2008) or even three Mediterranean species (Trabelsi et al., 2002a, 2002b, 2004; Astolfi et al., 2005; Francisco et al., 2008, 2011; Milana et al., 2008), including one lagoon form (A. lagunae) and one or two, (punctuated on the flanks "A. punctata" and non-punctuated "A. boyeri") marine forms. Since the genetic divergence values estimated between marine and lagoon A. boyeri populations were found to be similar to those existing between well-defined species of the same genus, the authors elevated them to the species rank. All of these studies pointed out the existence of an A. boyeri species complex, but for now there is no formal nor extensive description of the biology and distribution range of these putative species. The under-representation of southern populations from the western Mediterranean might have hindered the detection of additional genetic structure (e.g. Chaoui et al., 2009) or a good estimation of the potential species range, as the only data on this species in the Algerian coast are the study of A. boyeri species complex using otolith shape and somatic morphology at a local scale (Boudinar et al. 2015), and the age, growth and reproduction of Mellah lagoon population (Boudinar et al., 2016). Additionally the use of a single genetic marker, mostly mitochondrial, is not sufficient for precise species delimitation nor the identification of putative hybridization events. Finally an evaluation of the morphological differentiation of these taxa has not been performed in all cases. Indeed an integrative study including large geographical scope, multilocus and non molecular approaches appears as the best approach for species delimitation (Puillandre et al., 2012; Pante et al., 2015).

The purpose of the present work was to use otolith shape analysis and mitochondrial (Control Region: CR, Cytochrome b: Cyt $b$, ribosomal DNA 16S) and nuclear DNA (S7 intron 2) markers to study the morphological and genetic diversity of $A$. boyeri species complex from different habitat (lagoon, inlet, sea) in the western Mediterranean. This combination of 
1 investigative tools was attempted for the first time in this species complex and allowed

2 precising the species repartition and species limits in western Mediterranean.

3

4

5

6

7

8

\section{Materials and methods}

\subsection{Sampling sites}

Nine populations of Atherina boyeri including freshwater/brackish, marine punctuated (Fig. 1a) and marine unpunctuated fishes (Fig. 1b) were sampled from eight locations in the northern and southern banks of the western Mediterranean Sea (Fig. 2 and Table 1) representing different geographical areas (Algerian, Tunisian and French coasts and lagoons) and different environments: inshore brackish lagoons and the nearshore marine environment (hereafter called lagoon and sea habitats respectively) and inlets. All specimens were morphologically identified, according to Marfin (1981) and stored in 96\% ethanol.

\subsection{Otoliths morphometry}

Otolith shape analysis was performed on six of the nine populations, the same specimens being used for molecular analyses. Samples from Lion's Gulf and Mafragh inlet were discarded: as sampling size was too small for statistical analyses $(\mathrm{N}=7)$ and also because the specimens were fingerlings, which did not permit comparisons with adult fish. In order to eliminate fish size effects on otolith shape, all individuals used in this analysis belonged to the same size interval (5 to $8.5 \mathrm{~cm}$ Total Length, TL). A total of 362 fish were used for otolith shape analysis (Table 1). The sagittal otoliths were taken as pairs, washed in clean water, airdried and stored in plastic tubes. Both right and left otoliths were examined under a stereomicroscope fitted with a numerical camera (Lumenera's INFINITY lite) linked to a computer monitor. Otoliths were orientated in a consistent manner, with the sulcus side up. Numerical pictures were then acquired with TNPC software (Mahé et al., 2011). For each numerical image, the software Shape 1.2 (Iwata and Ukai, 2002) calculated the Fourier coefficients in order to make them invariants to the otolith size, orientation and position, regarding the beginning of the outline, which is arbitrarily defined (Crampton, 1995). Also, the Fourier Power (FP) spectrum was calculated to estimate the sufficient number of harmonics accounting for the best reconstruction of the otolith outline (Pothin et al., 2006). A subsample of 90 otoliths ( 10 samples $\times 7$ populations) was randomly created for this purpose. As the first 13 harmonics reached $99.99 \%$ of the mean cumulated power, the Fourier analysis indicated that the otolith shape could be summarized by these thirteen harmonics. A Factorial Discriminante Analysis (FDA) was performed with Fourier descriptors to compare otolith 
1 shape variations among the sampling areas using the SPSS software version 13 (SPSS, 2004).

2 Using Ward's method, a hierarchical clustering was performed with the FactoMineR package 3 with $\mathrm{R}^{\circledR}$ software (R Core Team 2014). The classification success of the discriminant analysis was checked using jackknifed cross-validation.

\subsection{Molecular analyses}

For molecular analysis, nine populations of A. boyeri species complex were collected from eight locations in the northern and southern banks of the western Mediterranean Sea representing variety in environment kinds of habitats (Fig. 1). Total DNA was extracted from caudal fin using $10 \%$ Chelex ${ }^{\circledR}$ with a $1 \mathrm{~h}$ proteinase $\mathrm{K}$ digestion followed by 15 min at $95^{\circ} \mathrm{C}$. Mitochondrial fragments of the control region (CR), 16rRNA, cytochrome $b$ (Cyt $b$ ) genes and nuclear fragment of the S7 intron 2 were amplified by polymerase chain reaction (PCR); the PCR conditions and primers sequences and corresponding references are given in Table 2. For each marker, other available sequences from Atherina were retrieved from GenBank. The PCR products were sent for Sanger sequencing at Eurofins MWG. The numbers of sequences used for each marker in each locality are given in Table 1.

\subsection{Species delimitation and population genetics analyses}

The sequences were aligned with ClustalW (Thompson et al., 1994). In addition to the alignments for each gene, a CR and Cyt $b$ concatenated alignment was performed as these markers presented the highest number of common sequences. Sequences of two Atheriniformes were used as outgroups: Leptatherina wallacei Prince, Ivantsoff \& Potter, 1982 belonging to the family Atherinidae (GenBank accession numbers AY326785.1 for CR, AY313118.1 for Cyt $b$ ) and Iso natalensis Regan, 1919 belonging to the family Isonidae (GenBank accession numbers HM855075.1 for 16S). We also added sequences of the only two other congeneric species in the area, A. presbyter (GenBank accession numbers JF309618.1) and A. hepsetus (GenBank accession numbers JF309620.1), in order to obtain the closest outgroups of the A. boyeri species complex. For further phylogenetic and phylogeographic analyses we added sequences from Genbank covering more localities (Table 3, Fig. 3, Table S1-S3; supplementary material). We used Jmodeltest 3.7 (Guindon and Gascuel, 2003; Posada, 2008) with the Akaike Information Criterion to identify the best-fit model of evolution for each locus to be used in Maximum-Likelihood (ML) analysis: $\mathrm{TVM}+\mathrm{G}$ for $\mathrm{CR}$ (gamma distribution shape parameter $\mathrm{G}=0.584)$, $\mathrm{TVM}+\mathrm{I}+\mathrm{G}$ for $\mathrm{Cyt} b(\mathrm{I}=$ $0.252, \mathrm{G}=0.649)$, TPM3uf $+\mathrm{G}$ for $16 \mathrm{~S}(\mathrm{G}=0.171)$, and $\mathrm{TIM} 3+\mathrm{G}$ for $\mathrm{S} 7(\mathrm{G}=1.221)$. ML 
analyses were performed with PhyML 3.0 (ref) and we tested the robustness of the inferred trees with 1000 bootstrap replicates (Felsenstein, 1985). Bayesian analyses (BA) were implemented in MrBayes 3.2 (Huelsenbeck and Ronquist, 2001; Ronquist and Huelsenbeck, 2003). The best-fit model of evolution for each locus was set using MrModeltest 2.3 (Nylander, 2004): $\mathrm{HKY}+\mathrm{G}$ for CR (gamma distribution shape parameter $\mathrm{G}=0.522$ ), $\mathrm{GTR}+\mathrm{I}+\mathrm{G}$ for Cyt $b(\mathrm{I}=0.332, \mathrm{G}=0.786), \mathrm{SYM}+\mathrm{G}$ for $16 \mathrm{~S}(\mathrm{G}=0.171)$, and $\mathrm{SYM}+\mathrm{G}$ for $\mathrm{S} 7$ $(\mathrm{G}=1.016)$. We used one independent run of two million generations of Markov chain Monte Carlo (MCMC) simulations for each marker to approximate posterior probabilities of phylogenetic trees. Topologies were sampled every 1000 generations, and a majority-rule consensus tree was estimated after discarding the first 2500 sampled generations.

The obtained sequences were used for a phylogeographic analysis. For each marker data set, we analyzed the total amount of genetic variance into three variance components: among groups, among populations within groups and within populations, using an analysis of molecular variance (AMOVA) in Arlequin v3.5 (Excoffier and Lisher, 2010). Samples were grouped by geographic proximity, habitat type or a combination of both, resulting in five different groupings (Table 4). According to the analyzed marker, some test combination may be absent due to the lack of sequence in those localities. The analysis was based on $\Phi_{\text {st }}$ (Excoffier et al., 1992), and its significance was tested through 1000 permutations. The significance of tests involving multiple comparisons was adjusted with a Bonferroni correction. Average number of nucleotide substitutions per site, Dxy (Nei, 1987) were used to estimate differentiation between populations using DNAsp v5 (Librado and Rozas, 2009).

\section{Results}

\subsection{Otoliths morphometry}

The first two discriminant functions of the FDA performed with Fourier descriptors accounted for $89.40 \%$ of the variance. Individuals could be discriminated into five groups based on the first two functions (Wilk's lambda $=0.07, \mathrm{p}<0.001$ ). Samples from Ziama inlet, marine punctuated individuals and unpunctuated marine specimens from Annaba's Gulf formed well separated groups. Specimens from Mellah and Mauguio lagoons formed another group. The last one includes individuals from Bizerte and Thau lagoons (Fig. 5). Overall areaclassification success was $84.30 \%$. The best reclassification rate is $84.03 \%$ for Annaba's Gulf punctuated marine specimens, then specimens from Ziama Inlet 75\%, Bizerte Lagoon 71.92\%, Mauguio Lagoon 66.07\%, Annaba's Gulf unpunctuated marine specimens $64.75 \%$, Mellah Lagoon specimens 55\%, and the Thau Lagoon individuals 53.48\% (Table 4). As for 
1 the molecular analysis, some of the Thau Lagoon specimens are scattered between lagoon and marine environment.

\subsection{Species delimitation}

In total, 373 bp (379 sequences) were sequenced from the CR, 464 bp (81 sequences) from the 16S, 315 bp (217 sequences) from the Cyt $b$ and 187 from the S7 (149 sequences) (including indels), yielding 170, 35, 72 and 27 haplotypes in A. boyeri species complex, respectively. The number of sequences used for the analysis includes the Genbank sequences. BA and ML species delimitation trees gave similar results in all cases.

For the Cyt $b, \mathrm{CR}, 16 \mathrm{~S}$, and the concatenated fragments CR and Cyt $b$, converged on a similar tree and showed the same topology. Seven clades were observed, A. presbyter and $A$. hepsetus, appeared as a sister group of the A. boyeri species complex. The five clades of the A. boyeri species complex: marine punctuated form, marine unpunctuated form, and two or three clades of the lagoonal form, are well supported by high bootstrap values.

The different clades of the lagoonal form correspond to different geographical areas: for the Cyt $b$ the first one grouped specimens from Greece (Nea Peramos-Kavala), the second grouped lagoon and insular Tunisian specimens, and the third clade grouped other of lagoonal populations. Four specimens from Thau lagoon, were grouped with lagoonal samples while the other specimens were grouped with the marine unpunctuated individuals (Figure S1; supplementary material).

For the $16 \mathrm{~S}$, three clades inside the lagoonal form, the first group exclusively Tunisian specimens from Bizerte lagoon, the second specimens from Bulgaria and Turkey, and the third one grouped other of lagoonal populations (Figure S1; supplementary material).

For the CR, three clades were observed, the first one grouped specimens from Tunisa, and Italy (Marsala and one specimen from Cagliari), the second grouped specimens from Turkey (Danube, Lake Sapanca) and one specimen from Croatia (Spalato). The third clade grouped other lagoonal samples.

The tree for CR includes the most localities and sample size is shown in Fig. 5, along with bootstrap and posterior probabilities values.

For the concatenated fragments CR and Cyt $b$, the lagoonal form is separated into two clades, one with the tunisian specimens and the other with those sampled from Algerian and French lagoons (Figure S1; supplementary material). 
1 The nuclear S7 marker did not lead to a well resolved phylogeny, but it allowed us to confirm

2 the grouping of some specimens from Thau with the lagoonal samples (presented in a rectangle on the tree) (Figure S2; supplementary material).

\subsection{Population genetics}

AMOVA results (Table 5) confirmed the existence of a significant genetic structure based on the three mt-DNA markers and showed a highly significant global structure when comparing lagoonal, marine unpunctuated and marine punctuated samples (1), $\mathrm{CR}\left(\mathrm{F}_{\mathrm{SC}}=0.66 ; \mathrm{F}_{\mathrm{ST}}=\right.$ $\left.0.92 ; \mathrm{F}_{\mathrm{CT}}=0.78 ; \mathrm{P}<0.001\right) ;$ Cyt $b\left(\mathrm{~F}_{\mathrm{SC}}=0.77 ; \mathrm{F}_{\mathrm{ST}}=0.94 ; \mathrm{F}_{\mathrm{CT}}=0.76 ; \mathrm{P}<0.001\right) ; 16 \mathrm{~S}\left(\mathrm{~F}_{\mathrm{SC}}=\right.$ $\left.0.77 ; \mathrm{F}_{\mathrm{ST}}=0.96 ; \mathrm{F}_{\mathrm{CT}}=0.82 ; \mathrm{P}<0.001\right)$.

The analysis based on Cyt $b$ between marine punctuated samples (2) shows a significant divergence among populations within groups $\left(\mathrm{F}_{\mathrm{SC}}=0.06 ; \mathrm{P}<0.001\right)$. No differences are observed within populations $\left(\mathrm{F}_{\mathrm{ST}}=0.61 ; \mathrm{P}=0.06\right)$ or among groups $\left(\mathrm{F}_{\mathrm{CT}}=0.58 ; \mathrm{P}=0.1\right)$.

Comparison based on Cyt $b$, between marine unpunctuated samples (3) show a significant differences among populations within groups $\left(\mathrm{F}_{\mathrm{SC}}=0.14 ; \mathrm{P}<0.001\right)$ and within populations $\left(\mathrm{F}_{\mathrm{ST}}=0.38 ; \mathrm{P}=0.06\right)$, no significant differences are observed among groups $\left(\mathrm{F}_{\mathrm{CT}}=0.28 ; \mathrm{P}=\right.$ $0.16)$.

The comparison between North, South Ouest and South East Mediterranean lagoonal samples (4) also revealed significant differences, $\mathrm{CR}\left(\mathrm{F}_{\mathrm{SC}}=0.43 ; \mathrm{F}_{\mathrm{ST}}=0.82 ; \mathrm{P}<0.001 ; \mathrm{F}_{\mathrm{CT}}=0.68 ; \mathrm{P}=\right.$ $0.01)$; Cyt $b\left(\mathrm{~F}_{\mathrm{SC}}=0.16 ; \mathrm{F}_{\mathrm{ST}}=0.83 ; \mathrm{F}_{\mathrm{CT}}=0.80 ; \mathrm{P}<0.001\right) ; 16 \mathrm{~S}\left(\mathrm{~F}_{\mathrm{SC}}=0.17 ; \mathrm{P}<0.001 ; \mathrm{F}_{\mathrm{ST}}=\right.$ $0.83 ; \mathrm{P}=0.02)$, based on $16 \mathrm{~S}$ no significant differences were observed among groups $\left(\mathrm{F}_{\mathrm{CT}}=\right.$ $0.80 ; \mathrm{P}=0.38)$.

Significant differences were also found while comparing lagoonal samples as observed in the tree topology, based on $\mathrm{CR}\left(\mathrm{F}_{\mathrm{SC}}=0.70 ; \mathrm{F}_{\mathrm{ST}}=0.82 ; \mathrm{P}<0.001 ; \mathrm{F}_{\mathrm{CT}}=0.41 ; \mathrm{P}=0.01\right)$.

The average number of nucleotide substitutions per site between populations for the Cyt $b$ was respectively Dxy $=0.14$, Dxy $=0.15$ when comparing lagoonal sequences with marine unpunctuated and punctuated ones, and Dxy $=0.11$ when comparing marine unpunctuated and punctuated sequences. When we compare respectively $A$. hepsetus with lagoonal, marine unpunctuated and punctuated samples, the average number of nucleotide substitutions is Dxy $=0.17$, Dxy $=0.13$, Dxy $=0.14$. Those values are lower when comparing A. presbyter with lagoonal $($ Dxy $=0.14)$, marine unpunctuated $($ Dxy $=0.10)$ and punctuated $($ Dxy $=0.13)$ samples. The average number of nucleotide substitutions is the lowest when comparing $A$. hepsetus and A. presbyter (Dxy $=0.06)$. 
1 For the CR, when comparing lagoonal sequences with marine unpunctuated and punctuated

2 ones Dxy is respectively equal to 0.15 and 0.18 , and Dxy $=0.17$ when comparing marine unpunctated and punctuated sequences. When we compare respectively A. hepsetus with lagoonal, marine unpunctuated and punctuated samples, the average number of nucleotide substitutions is Dxy $=0.21, \mathrm{Dxy}=0.16$, Dxy $=0.18$. In the other hand when we compare $A$. presbyter with lagoonal, marine unpunctuated and punctuated samples the average number of nucleotide substitutions is respectively, Dxy $=0.20, \mathrm{Dxy}=0.19, \mathrm{Dxy}=0.16$, it lowest value is set when comparing A. hepsetus and A. presbyter (Dxy $=0.11)$.

For the $16 \mathrm{~S}$, when comparing lagoonal sequences with marine unpunctuated and punctuated ones Dxy is respectively equal to 0.08 and 0.07 , and Dxy $=0.07$ when comparing marine unpunctated and punctuated sequences. When we compare respectively A. hepsetus or A. presbyter with lagoonal, marine unpunctuated and punctuated samples, the average number of nucleotide substitutions is Dxy $=0.08$, Dxy $=0.07$, Dxy $=0.07$, and Dxy $=0.02$ when comparing A. hepsetus and A. presbyter.

\section{Discussion}

Otoliths are widely used in different studies, such as species identification (Aguirre and Lombarte, 1999; Parmentier et al., 2001) and may vary within species according to fish size, site, depth and/or other environmental factors (Begg et al., 2001; Stransky and MacLellan, 2005; Hüssy, 2008). Several studies have shown that shape analysis allowed discrimination of local fish stocks according to ecological factors (Smith, 1992; Friedland and Reddin, 1994; Bolles and Begg, 2000; Cardinale et al., 2004). But this raises the question of the genetic versus environmental determinism (i.e. plasticity) of otolith shape.

In the present study, otolith shape analysis showed five groups: The first one included Mellah and Mauguio lagoons samples, when the second gathered individuals from Bizerte and Thau lagoons, the remaining samples (Ziama inlet, marine punctuated specimens and marine unpunctuated specimens from Annaba's gulf) constitute each a well separated group. Those results corresponds to what have been found by Boudinar et al. (2015) in a local study on the same Algerian populations, where differences were observed between Mellah lagoon, Ziama inlet, marine punctuated specimens and marine unpunctuated specimens from Annaba's gulf, using otolith shape and somatic morphology. Three different mtDNA markers (CR, Cyt $b$, $16 \mathrm{~S}$ ) corroborated otolith shape findings. Both gave us information about how much the punctuated and unpuctuated marine forms are different. Beside, an intra-specific variation into the lagoonal form of $A$. boyeri species complex using both methods was apparent. Molecular 
1 results for the three mtDNA markers using different tree construction methods are consistent

2 and allow us to distinguish seven separated groups. Two of them perfectly corresponded to two species already recognized as valid (A. hepsetus (A) and A. presbyter (B)) and three additional corresponded to the marine punctuated $A$. punctata (C), marine unpunctuated $A$. boyeri (D) and lagoonal A. lagunae (E) traditionally included in the A. boyeri species complex (Trabelsi et al., 2002b). The main clade grouped lagoon samples (Bizerte, Mauguio, Mellah) and fresh water samples (Ziama and Mafragh inlets). The remaining two clades correspond to punctuated and unpunctuated marine groups, in which we found respectively marine punctuated samples from Annaba Gulf and marine unpunctuated samples from Annaba and Lion's Gulf. Those clades are supported with high bootstraps and posterior probabilities. The divergence between them was comparable to that separating A. presbyter from A. hepsetus thereby supporting the potential species status of the different clades inside the A. boyeri species complex. The observation of misplaced individuals in the species tree was interpreted as the possibility of rare migration events and supported the hypothesis of gene flow among populations. The inter-lagoon difference has already been reported by Trabelsi et al., (2002b) who found an important genetic divergence between Tunisian and French lagoon sand smelts which is supported by high bootstrap values, suggesting that there has been a long-term barrier to the gene flow between these two populations. This was also reported by Astolfi et al., (2005) in a larger scale considering populations from Atlantic, Mediterranean and Black Sea lagoon, were an important and significant genetic structure was observed, with some groupings displaying low bootstraps values. Milana et al., (2012) along the Italian and Albanian coasts of the Mediterranean Sea where a pronounced spatial genetic structure has been detected by microsatellites among lagoon populations of $A$. boyeri species complex with different statistical approaches used.

The distinctiveness of the three species of the A. boyeri species complex using both molecular and otoliths shape analysis is observed across the eastern and western basins of the Mediterranean Sea. These results support the findings based on morphometric data (Kartas and Trabelsi 1990; Trabelsi et al., 2002a, 2004), Cyt $b$ gene (Trabelsi et al., 2002b), and mtDNA control region (Astolfi et al., 2005). Francisco et al., (2008) confirmed these results with further mtDNA fragments (control region and 12S), while Milana et al., (2008) in their analysis of portion of the mitochondrial cytochrome $b$, detected the presence of an insertion common to lagoon and punctuated forms of A. boyeri species complex. (88\% sequence identity of the insertion was found for marine punctuated form. $93 \%$ sequence identity of the 
1 insertion for the lagoon form. And 47\% similarity when comparing the insertions for the two

2 forms). Using three mtDNA markers (CR, 12S, 16S) and two nuclear markers (Rhodopsin and

$3 \quad$ S7 intron 2) Francisco et al., (2011) sustained the previous the previous results.

4 These differences may have a genetic determinism linked to a local selective process

5 potentially and / or habitat choice or (Lemaire et al., 2000; Chaoui et al., 2012). This could

6 also correspond to morphological plasticity (e.g. Capoccioni et al., 2011) or to a combination

7 of environmental and genetic effects. Most likely, the reason for A. boyeri to appear as a

8 complex clade is related to it distinct life cycle which is, among the other species, the one

9 most associated with more fragmented environments (lagoons, estuaries and freshwater bodies). The combination between this fragmentation in its habitats linked to the low dispersal ability of the species is probably responsible for the highly phylogeographic pattern observed.

Our results reinforce the species status of the three Mediterranean forms traditionally included in the A. boyeri species complex using both of otolith shape and mitochondrial DNA markers. A formal description and range distribution definition should be considered as a priority for this species, with further phylogeographic investigations including wider sampling and additional molecular genetic markers.

\section{Acknowledgements}

This work is funded in part by PHC-Maghreb research program (Partenariat Hubert Curien $\mathrm{N}^{\circ}$ 12MDU880M). The authors thank also the Algerian Ministry for Higher education and scientific research (General directorate for scientific research and technology development, GDRSDT) which financially supported this study, within the framework of the National Funds of Research (NFR). 


\section{References}

Aguirre, H., Lombarte, A., 1999. Ecomorphological comparisons of sagittae in Mullus barbatus and M. surmuletus. Journal of Fish Biology 55, 105-114.

Almada, F., Almada, V., Guillemaud, T., Wirtz, P., 2005. Phylogenetic relationships of the north-eastern Atlantic and Mediterranean blenniids. Biological Journal of the Linnean Society 86, 283-295.

Astolfi, L., Dupanloup, I., Rossi, R., Bisol, P., Faure, E., Congiu, L., 2005. Mitochondrial variability of sand smelt Atherina boyeri populations from north Mediterranean coastal lagoons. Marine Ecology Progress Series 297, 233-243.

Begg, G.A., Overholtz, W.J., Munroe, N.J., 2001. The use of internal otolith morphometrics for identification of haddock (Melanogrammus aeglefinus) stocks on Georges Bank. Fishery Bulletin 99, 1-14.

Bianchi, C.N., Morri, C., Chiantore, M., Montefalcone, M., Parravicini, V., Rovere, A., 2012. Mediterranean Sea biodiversity between the legacy from the past and a future of change. Life in the Mediterranean Sea: a look at habitat changes. New York: Nova Science Publishers, 1-55.

Bolles, K., Begg, G., 2000. Distinction between silver hake (Merluccius bilinearis) stocks in US waters of the northwest Atlantic based on whole otolith morphometrics. Fishery Bulletin 98, 451-462.

Borsa, P., Collet, A., Durand, J.D., 2004. Nuclear-DNA markers confirm the presence of two anchovy species in the Mediterranean. Comptes rendus biologies 327, 1113-1123.

Boudinar, A.S., Chaoui, L., Mahe, K., Cachera, M., Kara, M.H., 2015. Habitat discrimination of big scale sand smelt Atherina boyeri Risso, 1810 (Atheriniformes: Atherinidae) in eastern Algeria using somatic morphology and otolith shape. Ital. J. Zool. 82, 446453.

Boudinar, A.S., Chaoui, L., M., Kara, M.H., 2016. Age, growth and reproduction of the sand smelt Atherina boyeri Risso, 1810 in Mellah Lagoon (eastern Algeria). J. Appl. Ichthyol. 32, 302-309.

Cammarata, M., Mauro, A., Mazzola, A., Scilipoti, D., Arculeo, M., Parrinello, N., 1996. A biochemical genetic study of isoenzyme polymorphism within and between two populations of Atherina boyeri Risso. Genetika 32, 1220-1224.

Cantatore, P., Roberti, M., Pesole, G., Ludovico, A., Milella, F., Gadaleta, M.N., Saccone, C., 1994. Evolutionary analysis of cytochrome $b$ sequences in some Perciformes 
evidence for a slower rate of evolution than in mammals. Journal of Molecular Evolution 39, 589-597.

Capoccioni, F., Costa, C., Aguzzi, J., Menesatti, P., Lombarte, A., Ciccotti, E., 2011. Ontogenetic and environmental effects on otolith shape variability in three Mediterranean European eel (Anguilla anguilla, L.) local stocks. Journal of Experimental Marine Biology and Ecology 397, 1-7.

Cardinale, M., Doering-Arjes, P., Kastowsky, M., Mosegaard, H., 2004. Effects of sex, stock, and environment on the shape of known-age Atlantic cod (Gadus morhua) otoliths. Canadian Journal of Fisheries and Aquatic Sciences 61, 158-167.

Chaoui, L., Quignard, J.P., Kara, M.H., 2001. Différenciation morphologique de deux populations marine et lagunaire de daurade Sparus aurata (Linné, 1785). Rapport de la Commission Internationale pour l'Exploration Scientifique de la Mer Méditerranée 36, 371.

Chaoui, L., Kara, M. H., Quignard, J. P., Faure, E., Bonhomme, F., 2009. Forte différenciation génétique de la daurade Sparus aurata (L., 1758) entre les deux rives de la Méditerranée occidentale. Comptes Rendus Biologies 332, 329-335.

Chaoui, L., Gagnaire, P.A., Guinand, B., Quignard, J.P., Tsigenopoulos, C., Kara, M.H., 2012. Microsatellite length variation in candidate genes correlates with habitat in the gilthead sea bream Sparus aurata. Molecular ecology 21, 5497-5511.

Chow, S., Hazama, K., 1998. Universal PCR primers for S7 ribosomal protein gene introns in fish. Molecular Ecology 7, 1247-1263.

Crampton, J.S., 1995, Elliptic Fourier shape analysis of fossil bivalves, practical considerations. Lethaia 28, 179-186.

Excoffier, L., Lischer, H.E.L., 2010. Arlequin suite ver 3.5: a new series of programs to perform population genetics analyses under Linux and Windows. Mol. Ecol. Resour. $10,564-567$.

Excoffier, L., Smouse, P.E., Quattro, J.M., 1992. Analysis of molecular variance inferred from metric distances among DNA haplotypes: application to human mitochondrial DNA restriction data. Genetics 131, 479-491.

Felsenstein, J., 1985. Confidence limits on phylogenies: an approach using the bootstrap. Evolution 39, 783-791.

Focant, B., Trabelsi, M., Kartas, F., Quignard, J.P., 1992. Caractérisation biochimique de trois populations d'Atherina boyeri des milieux lagunaires méditerranéens. Rapport de la 
Commission Internationale pour l'Exploration Scientifique de la Mer Méditerranée 33, 94.

Focant, B., Trabelsi, M., Vandewalle, P., Kartas, F., Quignard, J.P., 1993. Apport de l'analyse biochimique à la caractérisation de populations d'Atherina boyeri des milieux lagunaires méditerranéens Actes du colloque Okeanos, «Le système littoral méditerranéen», Montpellier, 145-148.

Focant, B., Rosecchi, E., Crivelli, A.J., 1999. Attempt at biochemical characterization of sand smelt Atherina boyeri Risso, 1810 (Pisces, Atherinidae) populations from the Camargue (Rhône delta, France). Comparative Biochemistry and Physiology Part B: Biochemistry and Molecular Biology 122, 261-267.

Francisco, S.M., Congiu, L., Stefanni, S., Castilho, R., Brito, A., Ivanova, P.P., Levy, A., Cabral, H., Kilias, G., Doadrio, I., Almada, V.C., 2008. Phylogenetic relationships of the North-eastern Atlantic and Mediterranean forms of Atherina (Pisces, Atherinidae). Molecular Phylogenetics and Evolution 48, 782-788.

Francisco, S.M., Congiu, L., von der Heyden, S., Almada, V.C., 2011. Multilocus phylogenetic analysis of the genus Atherina (Pisces: Atherinidae). Molecular Phylogenetics and Evolution 61, 71-78.

Friedland, K., Reddin, D., 1994. Use of otolith morphology in stock discriminations of Atlantic salmon (Salmo salar). Canadian Journal of Fisheries and Aquatic Sciences 51, 91-98.

Gon, O., Ben-Tuvia, A., 1983. The biology of Boyer's sand smelt, Atherina boyeri Risso in the Bardawil Lagoon on the Mediterranean coast of Sinai. Journal of Fish Biology 22, 537-547.

Guindon, S., Gascuel, O.A., 2003. Simple, fast, and accurate algorithm to estimate large phylogenies by maximum likelihood. Systematic Biology 52, 696-704.

Henderson, P., Bamber, R., 1987. On the reproductive biology of the sand smelt Atherina boyeri Risso (Pisces: Atherinidae) and its evolutionary potential. Biological Journal of the Linnean Society 32, 395-415.

Huelsenbeck, J.P., Ronquist, F., 2001. MRBAYES: Bayesian inference of phylogeny. Bioinformatics 17, 754-755.

Hüssy, K., 2008. Otolith shape in juvenile cod (Gadus morhua): Ontogenetic and environmental effects. Journal of Experimental Marine Biology and Ecology 364, 3541. 
Iwata, H., Ukai, Y., 2002. SHAPE: a computer program package for quantitative evaluation of biological shapes based on elliptic Fourier descriptors. Journal of Heredity 93, 384385.

Kartas, F., Trabelsi, M., 1990. Sur le polymorphisme de l'athérine, Atherina boyeri Risso, 1810 (Atherinidae) des eaux littorales tunisiennes. Cybium 14, 295-311.

Kiener, A., Spillmann, C.J., 1969. Contribution à l'étude systématique et écologique des athérines des côtes françaises. Mémoires du Muséum national d'Histoire naturelle Série A : Zoologie 60, 33-74.

Klossa-Kilia, E., Prassa, M., Papasotiropoulos, V., Alahiotis, S., Kilias, G., 2002. Mitochondrial DNA diversity in Atherina boyeri populations as determined by RFLP analysis of three mtDNA segments. Heredity 89, 363-370.

Klossa-Kilia, E., Papasotiropoulos, V., Tryfonopoulos, G., Alahiotis, S., Kilias, G., 2007. Phylogenetic relationships of Atherina hepsetus and Atherina boyeri (Pisces: Atherinidae) populations from Greece, based on mtDNA sequences. Biological Journal of the Linnean Society 92, 151-161.

Kottelat, M., 1997. European freshwater fishes. Biologia 52, 1-271.

Kraitsek, S., Klossa-Kilia, E., Papasotiropoulos, V., Alahiotis, S.N., Kilias, G., 2008. Genetic divergence among marine and lagoon Atherina boyeri populations in Greece using mtDNA analysis. Biochemical genetics 46, 781-798.

Krijgsman, W., Hilgen, F.J., Raffi, I., Sierro, F.J., Wilson, D.S., 1999. Chronology, causes and progression of the Messinian salinity crisis. Nature 400, 652-655.

Lemaire, C., Allegrucci, G., Naciri, M., Bahri-Sfar, L., Kara, M.H., Bonhomme, F., 2000. Do discrepancies between microsatellite and allozyme variation reveal differential selection between sea and lagoon in the sea bass (Dicentrarchus labrax)?. Molecular ecology $9,457-467$.

Librado, P., Rozas J., 2009. DnaSP v5: a software for comprehensive analysis of DNA polymorphism data. Bioinformatics 25, 1451-1452.

Mahé, K., Fave, S., Couteau, J., 2011. TNPC : User guide. Version 5. Boulogne-sur-mer: Ifremer Institute. Computer Program.

Marfin, J. I., 1981. Biologie de 1'Atherine: Arherina boyeri Risso, 1810 (Poissons téléostéen) dans trois milieux saumâtres du Roussillon (Leucate, Canet, Bourdigou). Ph.D. Thesis. University of Perpignan, Montpellier. 
Mauro, A., Arculeo, M., Mazzola, A., Parrinello, N., 2007. Are there any distinct genetic subpopulations of sand smelt, Atherina boyeri (Teleostei: Atherinidae) along Italian coasts? Evidence from allozyme analysis. Folia Zoologica 56, 194-200.

Meyer, A., Kocher, T.D., Basasibawaki, P., Wilson, A.C., 1990. Monophyletic origin of Lake Victoria's cichlid fishes suggested by mitochondrial DNA sequences. Nature 347, $550-553$.

Milana, V., Sola, L., Congiu, L., Rossi, A., 2008. Mitochondrial DNA in Atherina (Teleostei, Atheriniformes): differential distribution of an intergenic spacer in lagoon and marine forms of Atherina boyeri. Journal of Fish Biology 73, 1216-1227.

Milana, V., Franchini, P., Sola, L., Angiulli, E., Rossi, A.R., 2012. Genetic structure in lagoons: the effects of habitat discontinuity and low dispersal ability on populations of Atherina boyeri. Marine biology 159, 399-411.

Nylander, J.A.A., 2004. MrModeltest v2. Program distributed by the author. Evolutionary Biology Centre, Uppsala University.

Nei, M., 1987. Molecular Evolutionary Genetics. Columbia University Press, New York.

Ostellari, L., Barglloni, L., Penzo, E., Patarnello, P., Patarnello, T., 1996. Optimization of single-strand conformation polymorphism and sequence analysis of the mitochondrial control region in Pagellus bogaraveo (Sparidae, Teleostei): rationalized tools in fish population biology. Animal Genetics 27, 423-427.

Pante, E., Puillandre, N., Viricel, A., Arnaud-Haond, S., Aurelle, D., Castelin, M., Chenuil, A., Destombe, C., Forcioli, D., Valero, M., Viard, F., Samadi, S., 2015. Species are hypotheses: avoid connectivity assessments based on pillars of sand. Molecular ecology 24, 525-544.

Parmentier, E., Vandewalle, P., Lagardère, F., 2001. Morpho-anatomy of the otic region in carapid fishes: eco-morphological study of their otoliths. Journal of Fish Biology 58, 1046-1061.

Patarnello, T., Volckaert, F.A.M., Castilho, R., 2007. Pillars of Hercules: is the AtlanticMediterranean transition a phylogeographical break? Mol. Ecol. 16, 4426-4444.

Posada, D., 2008. JModeltest: phylogenetic model averaging. Molecular Biology and Evolution 25, 1253-1256.

Pothin, K., Gonzalez-Salas, C., Chabanet, P., Lecomte-Finiger, R., 2006. Distinction between Mulloidichthys flavolineatus juveniles from Reunion Island and Mauritius Island (south-west Indian Ocean) based on otolith morphometrics. Journal of Fish Biology 69, 38-53. 
1 Puillandre, N., Modica, M.V., Zhang, Y., Sirovich, L., Boisselier, M.C., Cruaud, C., Samadi S., 2012. Large $\square$ scale species delimitation method for hyperdiverse groups. Molecular ecology 21, 2671-2691.

Quignard, J.P., Pras, A., 1986. Atherinidae. In: Whitehead, P., Bauchot, M.L., Hureau, J.C., Nielsen, J., Tortonese, E. (Eds.), Fishes of the North-eastern Atlantic and the Mediterranean. UNESCO, Paris, pp. 1207-1210.

R Core Team. 2014. R: A language and environment for statistical computing. R Foundation for Statistical Computing, Vienna, Austria. Available: http://www.R-project.org/. Accessed Apr 201422.

Ronquist, F., Huelsenbeck, J.P., 2003. MRBAYES 3: Bayesian phylogenetic inference under mixed models. Bioinformatics 19, 1572-1574.

Santos, R.S., Porteiro, F.M., Barreiros, J.P., 1997. Marine Wshes of the Azores: annotated checklist and bibliography. Bull Univ Azores, 1, 244

Smith, M.K., 1992. Regional differences in otolith morphology of the deep slope red snapper Etelis carbunculus. Canadian Journal of Fisheries and Aquatic Sciences 49, 795-804.

SPSS, 2004. SPSS for Windows, Version 13.0. Chicago, SPSS Inc. Computer Program.

Stransky, C., MacLellan, S.E., 2005. Species separation and zoogeography of redfish and rockfish (genus Sebastes) by otolith shape analysis. Canadian Journal of Fisheries and Aquatic Sciences 62, 2265-2276.

Thompson, J.D., Gibson, T.J., Plewniak, F., Jeanmougin, F., Higgins, D.G., 1997. The Clustal X windows interface: flexible strategies for multiple sequence alignment aided by quality analysis tools. Nucleic Acids Research 25, 4876-4882.

Trabelsi, M., Faure, E., Quignard, J.P., Boussaid, M., Focant, B., Maamouri, F., 2002a. Atherina punctata and Atherina laguna (Pisces, Atherinidae) new species found in the Mediterranean sea, Article 1: morphological investigations of three Atherinid species. Comptes Rendus de l'Académie des Sciences Paris Life Science 325, 967-975.

Trabelsi, M., Gilles, A., Fleury, C., Quignard, J.P., Maamouri, F., Faure, E., 2002b. Atherina punctata and Atherina lagunae (Pisces, Atherinidae), new species found in the Mediterranean Sea. Article 2: molecular investigations of three Atherinid species. Comptes Rendus de l'Académie des Sciences Paris Life Science 325, 1119-1128.

Trabelsi, M., Maamouri, F., Quignard, J.P., Boussaïd, M., Faure, E., 2004. Biometric and molecular investigations evidenced allopatric speciation in western Mediterranean lagoons within the Atherina lagunae species (Teleostei, Atherinidae). Estuarine, Coastal and Shelf Science 61, 713-723. 


\section{ACCEPTED MANUSCRIPT}

1

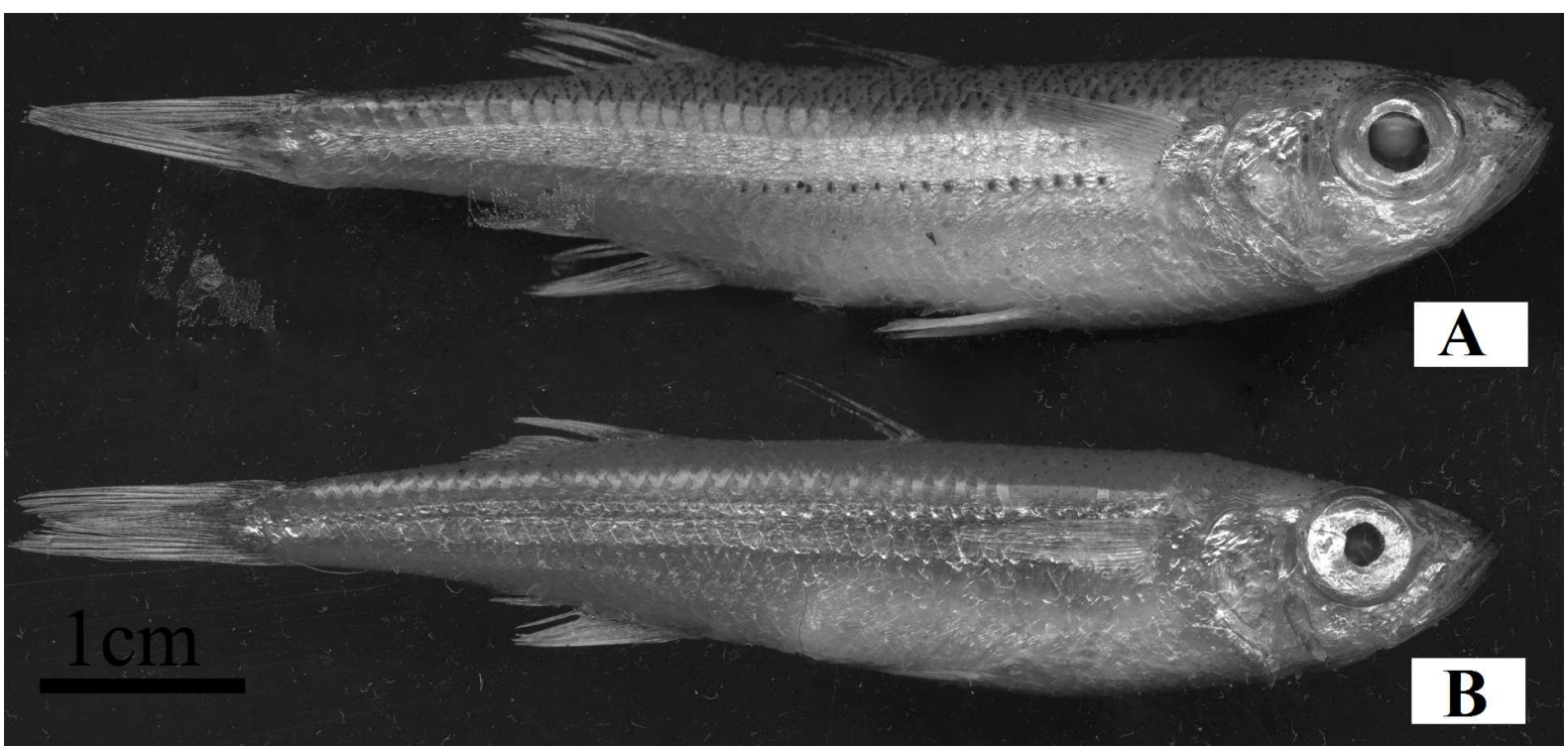

3 Fig. 1. Marine punctuated (A) and marine unpuntuated (B) forms belonging to Atherina boyeri species 4 complex.

5

6

7

8

9

10

11

12

13

14

15

16

17

18

19

20

21 


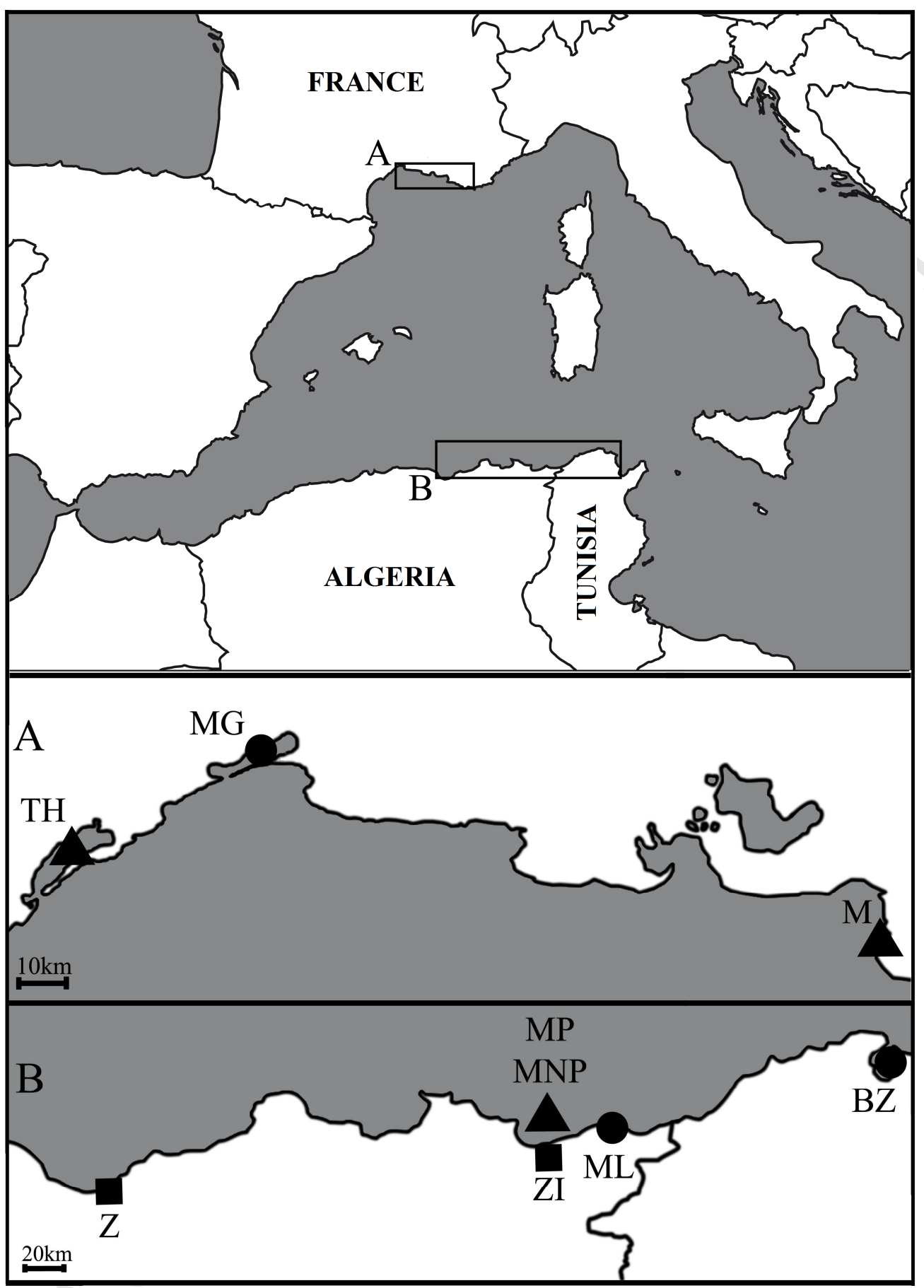

3 Fig. 2. Map of the study area. The eight sampling locations are indicated by their codes as

4 defined in Table 2. Circles indicate inshore lagoonal habitat, triangles marine habitat and

5 square inlet/brakish habitat. The upper map shows the north-western Mediterranean sampling

6 area, and the lower map shows the south-western Mediterranean sampling area. 


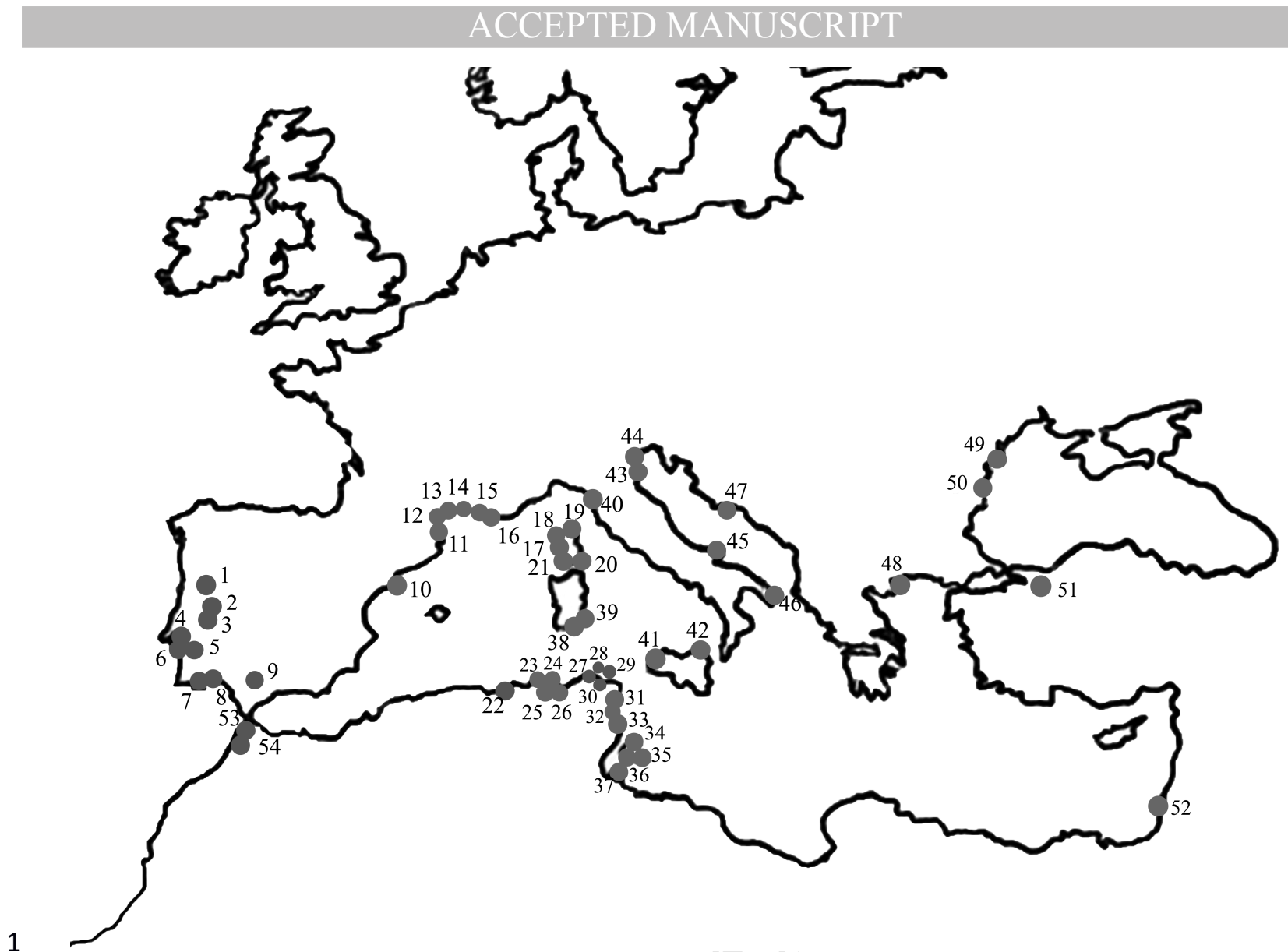

Fig. 3. Map of sampling locations for the extended analysis. The location numbers details are presented in table 3.

3

4

5

6

7

8

9

10

11

12 


\section{ACCEPTED MANUSCRIPT}
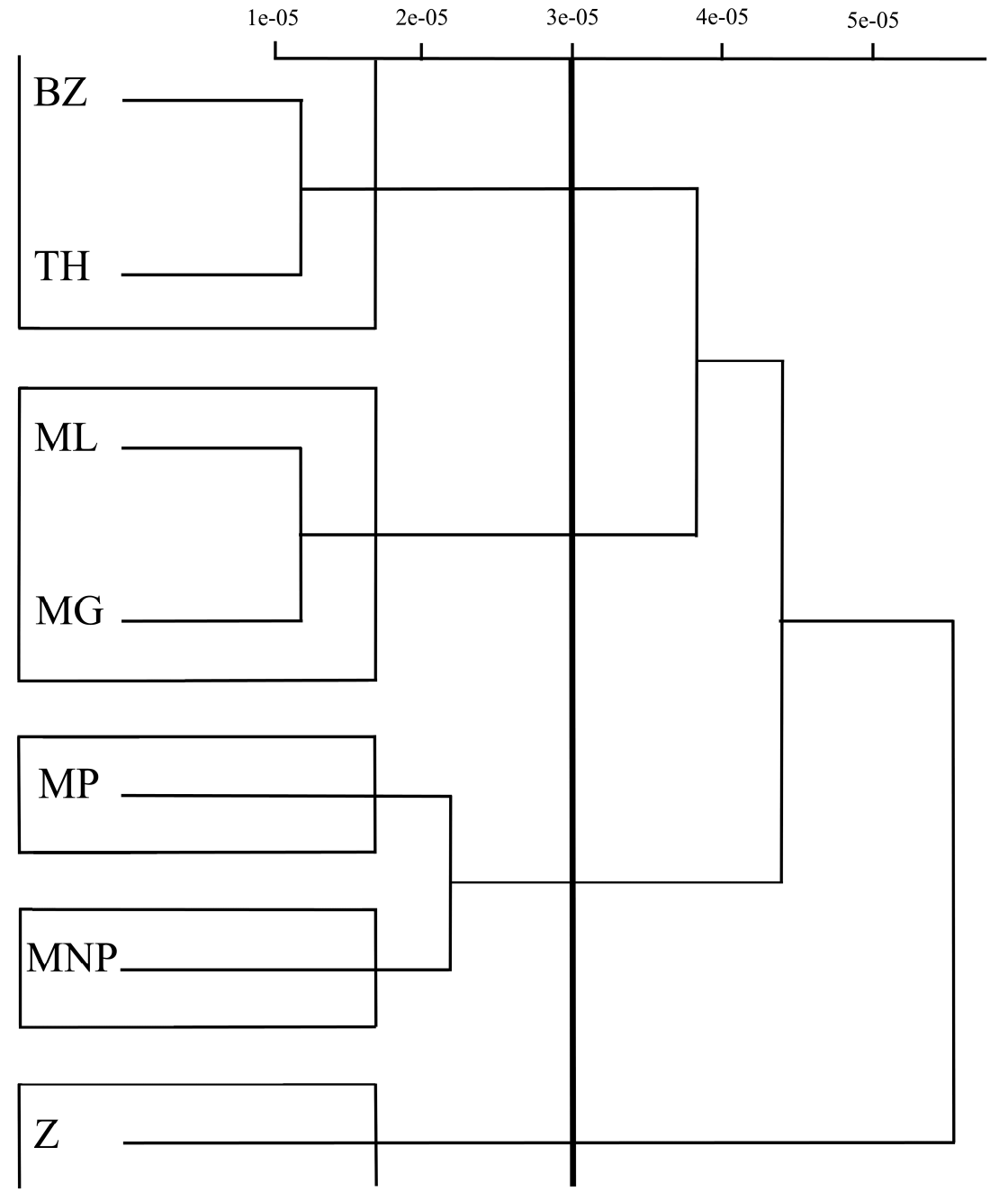

1

2 Fig. 4. Hierarchical clustering using Fourier's descriptors on otolith shape of A. boyeri species

3 complex. Sampling locations are indicated by their codes as defined in Table 2.

5

6

7

8

9

10 


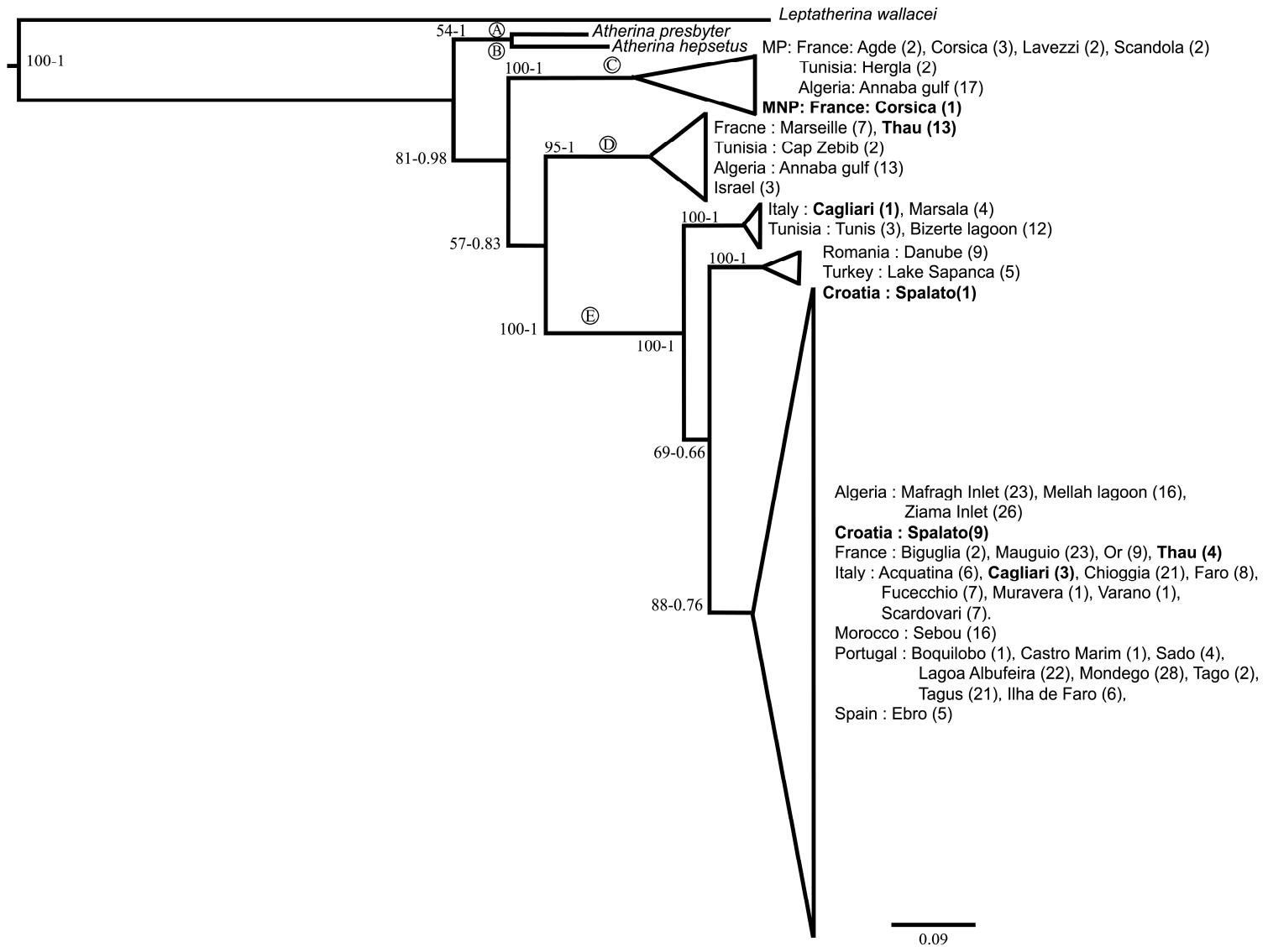

1

2 Fig. 5. Phylogenetic relationships within Atherina for the Control region (CR). Each main

3 node is represented by circled capital letters. (A) : A. hepsetus, (B) : A. presbyter, C) : A.

4 punctata, (D) : A. boyeri and (E) : A. lagunae). Percentages of bootstrap for maximum

$5 \quad$ likelihood are in bold followed by the posterior probability for Bayesian analysis.

6

7

8

9 
1 Table 1. Description of $A$. boyeri species complex samples including sampling locations,

2 samples codes, number of used sequences for each marker and number of otoliths for the

3 shape analysis in the western Mediterranean Sea region.

4

\begin{tabular}{|c|c|c|c|c|c|c|c|}
\hline Sampling locations & Country & Sample code & $\mathrm{CR}$ & Cyt $b$ & $16 \mathrm{~S}$ & S7 & Otoliths \\
\hline Annaba Gulf & \multirow{5}{*}{ Algeria } & $\mathrm{MP}$ & 16 & 12 & 7 & 7 & 61 \\
\hline Annaba Gulf & & MNP & 18 & 16 & 4 & 8 & 60 \\
\hline Mellah lagoon & & ML & 15 & 10 & 4 & 9 & 50 \\
\hline Mafragh Inlet & & MI & 22 & 24 & 9 & 10 & \\
\hline Ziama Inlet & & $\mathrm{Z}$ & 24 & 28 & 6 & 8 & 56 \\
\hline Bizerte lagoon & Tunisia & $\mathrm{BZ}$ & 17 & 8 & 4 & 7 & 57 \\
\hline Thau lagoon & \multirow{3}{*}{ France } & TH & 15 & 7 & 6 & 11 & 22 \\
\hline Mauguio lagoon & & MG & 21 & 20 & 8 & 9 & 56 \\
\hline Lion's Gulf & & $\mathrm{M}$ & 7 & 5 & 7 & 6 & \\
\hline
\end{tabular}

5

6

7

8

9

10 
1 Table 2. Primers and polymerase chain reaction conditions for each fragment.

\begin{tabular}{|c|c|c|c|c|}
\hline Fragment & Primer name & Sequence & Sequence Source & PCR conditions \\
\hline \multirow{2}{*}{ Control region } & L-pro1 & 5'-АСТСТCACСССТАGCTCCCAAAG-3' & \multirow{2}{*}{ (Ostellari et al., 1996) } & \multirow{2}{*}{$\begin{array}{c}94^{\circ} \mathrm{C} 2^{\prime} \\
35 \times\left(94{ }^{\circ} \mathrm{C} 30^{\prime \prime}, 55^{\circ} \mathrm{C} 30^{\prime \prime}, 72^{\circ} \mathrm{C} 1^{\prime}\right) \\
72^{\circ} \mathrm{C} 5^{\prime}\end{array}$} \\
\hline & H-DL1 & 5'-CCTGAAGTAGGAACCAGATGCCAG-3' & & \\
\hline \multirow[b]{2}{*}{ Cytochrome b } & New-For & 5'-AGCCTACGAAAACCCACCC-3' & (Meyer et al., 1990) & \multirow{2}{*}{$\begin{array}{c}92{ }^{\circ} \mathrm{C} 2 " \\
30 \times\left(92{ }^{\circ} \mathrm{C} 15^{\prime}, 52^{\circ} \mathrm{C} 45^{\prime}, 72{ }^{\circ} \mathrm{C} 1.5^{\prime \prime}\right) \\
72^{\circ} \mathrm{C} 8 "\end{array}$} \\
\hline & 34-Rev & $\begin{array}{c}5^{\prime}- \\
\text { AAACTGCAGCCCCTCAGAATGATATTTGTCCTCA- } \\
\text { 3' }\end{array}$ & (Cantatore et al., 1994) & \\
\hline \multirow{2}{*}{$16 \mathrm{~S}$} & 16SFor & 5'-AAGCCTCGCCTGTTTACCAA-3' & \multirow{2}{*}{ (Almada et al., 2005) } & \multirow{2}{*}{$\begin{array}{c}94{ }^{\circ} \mathrm{C} 3^{\prime} \\
35 \times\left(94{ }^{\circ} \mathrm{C} 45^{\prime}, 50^{\circ} \mathrm{C} 11^{\prime}, 72{ }^{\circ} \mathrm{C} 1^{\prime}\right) 72 \\
{ }^{\circ} \mathrm{C} 10^{\prime}\end{array}$} \\
\hline & 16SRev & 5'-CTGAACTCAGATCACGTAGG-3' & & \\
\hline \multirow{2}{*}{ S7 intron 2} & S7RPEX2F & 5'-AGCGCCAAAATAGTGAAGCC-3' & \multirow{2}{*}{$\begin{array}{l}\text { (Chow and Hazama, } \\
\text { 1998) }\end{array}$} & \multirow{2}{*}{$\begin{array}{c}94{ }^{\circ} \mathrm{C} 2^{\prime} \\
40 \times\left(95{ }^{\circ} \mathrm{C} 45^{\prime \prime}, 52^{\circ} \mathrm{C} 1,72{ }^{\circ} \mathrm{C} 45^{\prime}\right) 72 \\
{ }^{\circ} \mathrm{C} 10^{\prime}\end{array}$} \\
\hline & S7RPEX3R & 5'-GCCTTCAGGTCAGAGTTCAT-3' & & \\
\hline
\end{tabular}

2

3

4

5

6

7

8

9

10 
1 Table 3. Sampling location and number of Atherina boyeri species complex individuals used

2 in the extended phylogenetic analyses.

\begin{tabular}{|c|c|c|c|c|c|c|c|c|c|c|c|c|}
\hline \multirow[b]{2}{*}{$\mathrm{N}^{\circ}$ in Fig. } & \multirow{2}{*}{\multicolumn{2}{|c|}{ Collection site }} & \multicolumn{4}{|c|}{ lagoonal fish } & \multicolumn{3}{|c|}{ unpunctuated fish } & \multicolumn{3}{|c|}{ punctuated fish } \\
\hline & & & $\mathrm{N}$ & Cyt $b$ & $16 \mathrm{~S}$ & CR & Cyt b & $16 \mathrm{~S}$ & $\mathrm{CR}$ & Cyt $b$ & $16 \mathrm{~S}$ & $\mathrm{CR}$ \\
\hline 1 & Portugal & Mondego & 28 & & & 28 & & & & & & \\
\hline 2 & & Tagus & 21 & & 3 & 21 & & & & & & \\
\hline 3 & & Boquilobo & 1 & & & 1 & & & & & & \\
\hline 4 & & Tago & 2 & & & 2 & & & & & & \\
\hline 5 & & Sado & 4 & & & 4 & & & & & & \\
\hline 6 & & Lagoa Albufeira & 22 & & & 22 & & & & & & \\
\hline 7 & & Ilha de Faro & 6 & & & 6 & & & & & & \\
\hline 8 & & Castro Marim & 1 & & & 1 & & & & & & \\
\hline 9 & Spain & Zonar & 2 & & & 2 & & & & & & \\
\hline 10 & & Ebro & 5 & & & 5 & & & & & & \\
\hline & & Barcelona & 4 & & 4 & & & & & & & \\
\hline 11 & France & Ayrolle & 6 & 6 & & & & & & & & \\
\hline 12 & & Agde & 3 & & & & & & & 3 & 3 & 2 \\
\hline 13 & & Thau & 20 & & & & 20 & 3 & 17 & & & \\
\hline 14 & & Mauguio & 23 & 18 & 8 & 23 & & & & & & \\
\hline 15 & & Or & 9 & & & 9 & & & 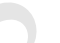 & & & \\
\hline 16 & & Marseille & 7 & & & & & & 7 & & & \\
\hline 17 & & Scandola & 7 & & & & 7 & & & & & \\
\hline 18 & & Scandola & 2 & & & & & & & 2 & 2 & 2 \\
\hline 19 & & Biguglia & 9 & 9 & & 2 & & & & & & \\
\hline 20 & & Lavezzi & 3 & & & & & & & 3 & 2 & 2 \\
\hline 21 & & Corsica & & & & & & & & & & 2 \\
\hline 22 & Algeria & Ziama Inlet & 27 & 25 & 5 & 27 & 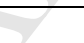 & & & & & \\
\hline 23 & & Annaba Gulf & 17 & & & & & & & 10 & 4 & 17 \\
\hline 24 & & Annaba Gulf & 13 & & & & 2 & 1 & 13 & & & \\
\hline 25 & & Mafragh Inlet & 23 & 22 & 9 & 23 & & & & & & \\
\hline 26 & & Mellah lagoon & 16 & 6 & 5 & 16 & & & & & & \\
\hline 27 & Tunisia & Bizerte lagoon & 12 & 5 & 3 & 12 & & & & & & \\
\hline 28 & & Cap Zebib & 4 & & & & & & & 4 & & \\
\hline 29 & & Cap Zebib & 8 & & & & 8 & 3 & 2 & & & \\
\hline 30 & & Tunis & 3 & & & 3 & & & & & & \\
\hline 31 & & Hergla & 10 & & & & 10 & & & & & \\
\hline 32 & & Hergla & 3 & & & & & & & 3 & & 2 \\
\hline 33 & & Monastir & 10 & & & & 10 & & & & & \\
\hline 34 & & Karkennah Sidi Fraj & 9 & 9 & & & & & & & & \\
\hline 35 & & Karkennah El Attaya & 7 & 7 & & & & & & & & \\
\hline 36 & & Karkennah Sidi Youssef & 6 & 6 & & & & & & & & \\
\hline 37 & & Djerba & 8 & 8 & & & & & & & & \\
\hline 38 & Italy & Cagliari & 4 & & & 4 & & & & & & \\
\hline 39 & & Muravera & 1 & 1 & & 1 & & & & & & \\
\hline 40 & & Fucecchio & 7 & & & 7 & & & & & & \\
\hline 41 & & Marsala & 4 & & & 4 & & & & & & \\
\hline 42 & & Faro & 8 & & & 8 & & & & & & \\
\hline 43 & & Scardovari & 7 & & & 7 & & & & & & \\
\hline 44 & & Chioggia & 21 & & 4 & 21 & & & & & & \\
\hline 45 & & Varano & 1 & 1 & & 1 & & & & & & \\
\hline 46 & & Acquatina & 6 & & & 6 & & & & & & \\
\hline 47 & Croatia & Spalato & 10 & & 4 & 10 & & & & & & \\
\hline 48 & Greece & Nea Peramos-Kavala & 2 & & & & & & 1 & & & 1 \\
\hline 49 & Romania & Danube & 9 & & & 9 & & & & & & \\
\hline 50 & Bulgaria & Bulgaria & 5 & & 5 & & & & & & & \\
\hline 51 & Turkey & Turkey & 3 & & 3 & & & & & & & \\
\hline & & Lake Sapanca & 5 & & & 5 & & & & & & \\
\hline 52 & Israel & Israel & 3 & & & & & 2 & 3 & & & \\
\hline 53 & Morocco & Loukkos & 4 & & 4 & & & & & & & \\
\hline 54 & & Sebou & 16 & & & 16 & & & & & & \\
\hline
\end{tabular}


1 Table 4. Classification success rate using based on otolith shape of A. boyeri species complex

2 using jackknifed cross-validation. Sampling locations are indicated by their codes as defined 3 in Table 2.

\begin{tabular}{|c|c|c|c|c|c|c|c|}
\hline Sites & ML & MNP & MP & BZ & Z & MG & TH \\
\hline ML & 55 & 8 & 1 & 11 & 6 & 14 & 5 \\
\hline MNP & 5 & 79 & 9 & 0 & 11 & 10 & 8 \\
\hline MP & 1 & 8 & 100 & 3 & 3 & 1 & 3 \\
\hline BZ & 8 & 1 & 6 & 82 & 4 & 5 & 8 \\
\hline Z & 5 & 5 & 2 & 1 & 84 & 12 & 3 \\
\hline MG & 10 & 7 & 3 & 8 & 5 & 74 & 5 \\
\hline TH & 3 & 3 & 2 & 7 & 0 & 5 & 23 \\
\hline
\end{tabular}

4

5

6

7

8

9

10

11

12

13

14

15

16

17

18

19

20 
1 Table 5. AMOVA results for five different groupings, as a function of geographic proximity, 2 habitat type or a combination of both.

\begin{tabular}{|c|c|c|c|c|c|c|c|c|c|c|c|c|}
\hline & \multicolumn{4}{|c|}{$\mathrm{CR}$} & \multicolumn{4}{|c|}{ Cyt $b$} & \multicolumn{4}{|c|}{$16 \mathrm{~S}$} \\
\hline & $\mathrm{ddl}$ & Variation & F-statistics & P-value & ddl & Variation & F-statistics & P-value & $\mathrm{ddl}$ & Variation & F-statistics & P-value \\
\hline Among populations within groups & 2 & 78.67 & $\mathrm{FSC}=0.66$ & 0 & 2 & 76.67 & $\mathrm{FSC}=0.77$ & 0 & 2 & 82.81 & $\mathrm{FSC}=0.77$ & 0 \\
\hline Within populations & 38 & 14.16 & $\mathrm{FST}=0.92$ & 0 & 24 & 18.1 & $\mathrm{FST}=0.94$ & 0 & 16 & 13.31 & $\mathrm{FST}=0.96$ & 0 \\
\hline Among groups & 333 & 7.18 & $\mathrm{FCT}=0.78$ & 0 & 181 & 5.23 & $\mathrm{FCT}=0.76$ & 0 & 54 & 3.88 & $\mathrm{FCT}=0.82$ & 0 \\
\hline (2) Within MP & & & & & & & & & & & & \\
\hline Among populations within groups & & & & & 2 & 58.94 & $\mathrm{FSC}=0.06$ & 0 & & & & \\
\hline Within populations & & & & & 3 & 2.52 & $\mathrm{FST}=0.61$ & 0.0645 & & & & \\
\hline Among groups & & & & & 19 & 38.54 & $\mathrm{FCT}=0.58$ & 0.109 & & & & \\
\hline (3) Within MNP & & & & & & & & & & & & \\
\hline Among populations within groups & & & & & 2 & 28.77 & $\mathrm{FSC}=0.14$ & 0 & & & & \\
\hline Within populations & & & & & 3 & 10.07 & $\mathrm{FST}=0.38$ & 0.0009 & & & & \\
\hline Among groups & & & & & 51 & 61.16 & $\mathrm{FCT}=0.28$ & 0.1632 & & & & \\
\hline $\begin{array}{l}\text { (4) Lagoons: Med North/Med } \\
\text { South Ouest/Med South East }\end{array}$ & & & & & & & & & & & & \\
\hline Among populations within groups & 2 & 68.17 & $\mathrm{FSC}=0.43$ & 0 & 2 & 80.02 & $\mathrm{FSC}=0.16$ & 0 & 2 & 80.12 & $\mathrm{FSC}=0.17$ & 0 \\
\hline Within populations & 7 & 13.95 & $\mathrm{FST}=0.82$ & 0 & 8 & 3.25 & $\mathrm{FST}=0.83$ & 0 & 2 & 3.49 & $\mathrm{FST}=0.83$ & 0.028 \\
\hline Among groups & 114 & 17.88 & $\mathrm{FCT}=0.68$ & 0.014 & 110 & 16.73 & $\mathrm{FCT}=0.80$ & 0 & 24 & 16.39 & $\mathrm{FCT}=0.80$ & 0.385 \\
\hline $\begin{array}{l}\text { (5) Lagoon populations as in tree } \\
\text { topology }\end{array}$ & & & & & & & & & & & & \\
\hline Among populations within groups & 2 & 41.63 & $\mathrm{FSC}=0.70$ & 0 & & & & & & & & \\
\hline Within populations & 27 & 41.16 & $\mathrm{FST}=0.82$ & 0 & & & & & & & & \\
\hline Among groups & 275 & 17.21 & $\mathrm{FCT}=0.41$ & 0.017 & & & & & & & & \\
\hline
\end{tabular}

3

4 